\title{
Pathways to a Knowledge Society: A Proposal for a Hierarchical Model for Measuring Digital Literacy Among Israeli pre-service Teachers
}

\author{
Yehuda Peled ${ }^{1}$, Gila Kurtz ${ }^{2}$ and Orit Avidov-Ungar ${ }^{3}$ \\ ${ }^{1}$ Western Galilee College, Israel \\ ${ }^{2}$ Holon Institute of Technology, Israel \\ ${ }^{3}$ Achva Academic College, Israel \\ yehudap@wgalil.ac.il \\ Gilaku@hit.ac.il \\ avidovo@achva.ac.il
}

\begin{abstract}
This paper presents the results of an empirical study on validation of performance statements for an inventory of the digital literacy skills required for learning. These skills are used to determine digital readiness of pre-service teachers. The paper reports on validation of an adjusted set of 54 performance statements which were categorized into seven digital learning domains. The seven digital learning domains were validated based on structural equation modelling which was then confirmed by factor analysis using AMOS software. The results of the analysis indicate the existence of a multi-layered model where all digital learning domains are positively connected to each other. Our findings therefore suggest a strong statistical validity of the performance statement inventory. The findings also point to the fact that pre-service teachers are in a transit phase from digital immigrants to digital natives. That, in the context of Covid-19 pandemic, implies the need to invest in appropriate preparation and training of pre-service teachers to teach in an online environment. The inventory for measuring digital literacy can be used to assess teachers' digital readiness on a regular basis, thereby enabling them to adjust the teaching materials and pedagogy to achieve the required level of digital readiness, as defined by the school.
\end{abstract}

Keywords: digital literacies, digital readiness, students majoring in education, higher education.

\section{Introduction}

Digital literacy is one of the most important 21st-century competencies (Vavik and Salomon, 2016; Voogt et al., 2013). Teachers should possess digital literacy skills (DLs) so that they will be able to integrate these skills into their teaching. There is a growing gap between required classroom practices in the 21st century and teachers' use of digital technologies (Ata and Yıldırım, 2019). It is no longer sufficient for teachers and pre-service teachers to know how to use existing digital tools. They also need to be digitally literate, in order to critically evaluate such tools and platforms for safe, wise, and productive use (Akayoglu et al., 2020). A digitally literate teacher is expected to have numerous competencies, such as integrating technology into their teaching, based on a deep understanding of their subject matter pedagogy to improve teaching. To do so, they need to be familiar with a variety of relevant technology tools (Watt, 2019; Indriyani, 2019; Olurinola, 2020).

With the rapid changes in information and communication technologies, research in teacher education should focus on competencies in terms of digital literacy, and consider other variables that are related to digital literacy (Güneş and Bahçivan, 2018; Lawrence et al., 2020).

The emergence of smartphones, which began in 2007, represent, most of all, the influence of technology on society and social behaviour, which reflects on the Digital Literacy terminology. As digital literacy evolved, one can find various definitions for digital literacy (DL) (e.g., see Bawden, 2001; Gilster, 1997; Lankshear and Knobel, 2015; Mioduser, Nachmias and Forkosh-Baruch, 2008). Various research offered different explanations as to what constitutes the needed DLs for a learner (e.g., see Dede, 2010; Hockly, Dudeney and Pegrum, 2014; EshetAlkali and Amichai-Hamburger, 2004; Porat, Blau and Barak, 2018; Vinther and Lauridsen, 2018). There are only a few tools available to measure what DLs a learner possesses (e.g., see Jung and Latchem, 2011), thus there is an increased demand for DL assessment. This paper concludes the results of a second and final validation process of 54 performance statements (PSs), which represent seven digital learning domains (DLD's) out of the 64 original PSs of the digital literacy skills required for learning, which were described in a previous article (see Kurtz and Peled, 2016). The main purpose of the current research was to gather additional empirical evidence regarding the firmness of a digital literacies inventory of the 54 digital literacy skills developed by the research team, and test the study's theoretical model in order to confirm the DL assessment tool developed by Kurtz and 
Peled, (2016).The remainder of this current paper is succinctly articulated as follows: Section 2 discusses the related literature that is of immediate relevance to the current study. Section 3 presents the theoretical foundation that has guided the development of the proposed structural model. Section 4 presents the study methods, highlighting data collection and analysis. The details of the results are presented in Section 5. Section 6 consists of a discussion on the implications, limitations, and conclusion of the paper.

\section{Literature Review}

There is an increased demand for DL assessment. For instance Chetty et al. (2018) and Lyons et al. (2019) recommend that the $\mathrm{G} 20$ countries institute a digital literacy assessment, as standardized assessment tools are essential to consistently measure digital literacy, identify gaps and track progress towards narrowing them.

The plethora of definitions and conceptualizations of what digital literacies mean, reflect on the diversity in tools that aim to measure digital literacy practices. However, the majority of the existing digital literacy measuring tools are targeting a specific objective, occupation, or age group. One such tool is the digital literacy survey (http://www.digitalliteracy.eu), developed specifically for the European citizens and by the European Computer Driving Licence (ECDL) foundation. In this survey, there are two sections - first section includes questions regarding the perceptions of the participants, the second section includes questions for actual practices, but it fails to go beyond measuring technical skills. Similarly, Tyger (2011) developed a perceived digital literacy scale to measure teacher candidates' digital literacy, yet the scale items only ask participants' understanding of several ICT terms, such as spyware, weblog, tagging, hence focusing only on perceived ICT knowledge. Other similar instruments also use ICT competence scales (e.g., Hsu, 2010; Tondeur et al., 2017). A report written by Covello and Lei (2010) for a research project titled Analysis for Human Performance Technology Decisions demonstrates this tendency to focus on ICT skills for the measurement of digital literacies as well as the necessity to revise existing instruments regularly as technologies and learners' digital practices continue to evolve.

Some developed test efforts to measure students' ability to handle digital information, and to communicate and collaborate during problem solving (Siddiq, Gochyyev, and Wilson, 2017). Other research investigated digital literacy among junior high school students, with the aim of comparing perceptions of participants' digital literacy competencies and their actual performance in relevant digital tasks (Porat et al., 2018). A review of literature on assessment instruments of primary and secondary school students' ICT literacy, done by Siddiq et al. (2016), found a total of 38 ICT literacy tests reported in 66 studies. The results indicate that most of the tests target lower secondary students, thus making this instrument age specific. In regard to the feasibility of implementation of an assessment instrument, Fraenkel, Wallen and Hyun (2011) point out that the key features are validity, reliability, and some other factors to be considered for an ideal assessment instrument. They claim that the number of items and practicality of implementation are directly related to feasibility. Many of the current digital literacy assessment tools require lengthy time and effort in order to be implemented. For this reason, there is a need for a valid, reliable, and feasible digital literacy assessment scale.

Yang (2019) asserts that an assessment tool is needed to measure student digital literacy. Perdana, et al. (2019a) developed an open-ended test for measuring digital literacy skills of students, which was based on five components of digital literacy skill: information, communication, content creation, safety, and problem-solving - thus, missing some of the essential digital literacy components. In addition, we have identified a number of instruments measuring various aspects of digital literacies: a scale designed to measure self-efficacy for information literacy (Kurbanoglu et al., 2006); a self-report instrument to measure pre-service teachers' ICT competencies in education, comprising competencies to support pupils for ICT use in class, and competencies to use ICT for instructional design (Tondeur et al., 2017); an information literacy test for higher education, which aims to assess different levels of thinking skills (Boh Podgornik et al., 2016); an information literacy test to predict the strength of some attributes of digital nativeness (ICT ownership, ICT experiences, internet confidence and number of ICT-rich university courses) on the information literacy of university students (Šorgo et al., 2017), and a digital literacy scale for teenagers (Rodríguez-de-Dios et al., 2016). Literat's (2014, pp.15) instrument on new media literacy measures individuals' "new media literacy skills, media exposure, digital participation, and civic engagement", and considers both online and offline student behaviours. There's an endless report of digital literacy measurements without specifying the instrument used for acquiring the data (see: Promsri, 2019; Perdana et al., 2019b; Kuek and Hakkennes, 2019). Apart from Promsri (2019) who developed a scale called "Digital Literacy Awareness" to identify the association between digital literacy and social intelligence, none of the above are sufficiently broad to measure digital readiness in an ever changing technological environment. 
In 2017, G20 policy makers (a group of finance ministers and central bank governors from 19 of the world's largest economies and the European Union) argued that it is essential not to introduce a universal indicator to measure digital literacy, because, unlike literacy, the definition of digital literacy is contested, leading to the development of different and inconsistent sets of indicators for measuring digital literacy; instead, implement a "standardized, multidimensional [set of measures] of digital literacy" (Chetty et al., 2018). Following that, the UNESCO Institute for Statistics (UIS) undertook a mapping exercise to show countries how existing data collection instruments can be linked and used to produce internationally comparable results of digital literacies. The findings show that only a few of the existing 44 assessments which were reviewed are suitable to measure minimum proficiency in digital literacy on a global scale. Not even one single assessment tool to measure digital literacy has been endorsed by the report (Laanpere, 2019).

\section{A Digital Literacy Framework}

First, we will define the broad concept of digital literacy and then we will discuss various frameworks of digital competencies.

The rationale for formulating " $21^{\text {st }}$ Century Skills" is that unlike the $20^{\text {th }}$ century, the capabilities people require in the 21st century for work, leisure and citizenship, are very different (Dede, 2010). Thus, today's children need to learn new skills, "soft skills", namely, 21st century skills, which will enable them to cope with a continually changing world. As the Partnership for $21^{\text {st }}$ Century Skills (Bishop, 2015) states in its mission statement ${ }^{1}: 1$ ) Learning takes place throughout life in many places and spaces. From birth through their careers, learners need a broad range of experiences that develop their skills, dispositions, and abilities to succeed. A strong foundation for success is rooted in learning that happens in and out of school; 2) $21^{\text {st }}$-century learning environments and opportunities are essential to prepare all students for the challenges of work, life, and citizenship in the $21^{\text {st }}$ century and beyond. Thus, "learning to learn" is one of the required $21^{\text {st }}$-century skills (Binkley et al., 2012).

Among the set of skills required for the $21^{\text {st }}$ century are digital literacies, which might best be defined as "those capabilities which fit an individual for living, learning and working in a digital society" (Hibberson et al., 2015). In addition, the research literature includes a variety of definitions and criteria for digital literacy - some even overlap (Šorgo et al., 2017).

Kurtz and Peled (2016), aided by six educational technology researchers and seven ICT graduate students, identified seven digital learning domains (DLDs): (A) Information Collection; (B) Information Evaluation; (C) Information Management; (D) Information Processing; (E) Teamwork; (F) Integrity Awareness; and (G) Social Responsibility. These DLDs establish the framework for the self-assessment tool. The digital competencies and conceptual items described by Gilster (1997), Hobbs (2010), Mills (2010), Rheingold (2012), Janssen et al. (2013), Ribble (2016), Park (2016), and Roxin and Rusitoru (2016) easily map to the DLDs developed by Kurtz and Peled (2016).

Therefore, the organization of competencies and skill sets described in this section follows Kurtz and Peled's seven DLDs.

\subsection{Information Collection}

Foundational to most new literacies, is the ability to seek and find information within digital sites (Gilster, 1997; Hobbs, 2010; Kurtz and Peled, 2016; Ribble, 2016). This most basic skill expands to include initial considerations of actual need for information and know-how related to searching digital systems. Kurtz and Peled (2016) address this initial ability to identify and articulate the need for information, a task required before a search. In addition, Janssen et al. (2013) address the need for informed decisions supporting the use of appropriate digital technologies for researching.

\subsection{Information Evaluation}

Information Evaluation is a digital learning domain that, while foundational, can be a more cognitively demanding skill than Information Collection, Retrieval and Management. Not only do Kurtz and Peled (2016) support the ability to determine a source's credibility, they also include the skill required to determine if the information will meet the intended needs of a given task. Critical thinking is required (Gilster, 1997; Park, 2016;

\footnotetext{
${ }^{1}$ http://www.p21.org/about-us/our-mission
} 
Rheingold, 2012), as is mindful reflection (Gilster, 1997; Rheingold, 2012) and the ability to problem-solve (Roxin and Rusitoru, 2016). A digitally literate individual must be able to analyse, evaluate, understand and reflect on a given task and the information required to meet the need (Gilster, 1997; Hobbs, 2010).

\subsection{Information Management}

Kurtz and Peled (2016) describe information management from a very basic level referencing the ability to organize digital files. Like Information Collection and Retrieval, this is another foundational skill to many new literacies. However, Gilster (1997) and Janssen et al. (2013) extend this foundational concept a bit further. They speak of the need for self-efficacy of an individual in the ability to seamlessly navigate in a digital environment, while at the same time having the ability to process information received from multiple formats. They also express the need for digitally literate individuals to have the ability to learn about and with digital technologies, an increasing necessity as available technologies are evolving rapidly.

\subsection{Information Processing}

At its most basic level, processing, managing and presenting information involves content creation and knowledge assembly (Gilster, 1997; Hobbs, 2010; Park, 2016). Hobbs (2010, pp.31) explains that active participation in digital literacy practices "cultivate[s] an active approach to the process of meaning making". Yet, digital literacy includes more, moving beyond basic representation toward the use of multiple forms of digital media for creative expression (Janssen et al., 2013; Kurtz and Peled, 2016; Mills, 2010; Roxin and Rusitoru, 2016). There is Janssen et al., (2013) note, an intricate relationship between digital technologies and creative expression.

\subsection{Teamwork}

Team-based learning, like social responsibility, links to the need of individuals to work collaboratively in this participatory culture. Kurtz and Peled (2016) look closely at individual team members' awareness of their role, the roles of other team members, and the alignment of individual roles for the work of the group. Concern for collaborative engagement and the ability to construct social groups (Mills, 2010; Rheingold, 2012), as well as having the ability to share individual thoughts with group members (Gilster, 1997; Hobbs, 2010; Kurtz and Peled, 2016), are noted in the literature as being important competencies of digital literacy.

\subsection{Integrity Awareness}

Digital integrity encompasses the knowledge of common practices and compliance with copyright and the legal and ethical aspects associated with the use of digital media, including awareness and understanding of Creative Commons licenses and how to provide attribution (Gilster, 1997; Hobbs, 2010; Kurtz and Peled, 2016). Similarly, Janssen et al. (2013) include privacy and security, and legal and ethical aspects as competencies of digital literacy. They state the following for each, respectively:

The digitally competent person has the capacity to protect personal data and take appropriate security measures; [and] the digitally competent person behaves appropriately and in a socially responsible way in digital environments, demonstrating awareness and knowledge of legal and ethical aspects on the use of ICT and digital content (Janssen et al., 2013, pp.477).

Park (2016) provides details specific to digital literacy and security, including password protection, and Internet and mobile security related to hacking, scams and malware detection.

\subsection{Social Responsibility}

Social responsibility is a key component necessary for life in a participatory culture (Jenkins et al., 2006) in this emerging fourth industrial revolution driven by the digital economy (Baller, Dutta and Lanvin, 2016). Kurtz and Peled (2016) describe social responsibility as an awareness of threatening situations and understanding of social consequences related to one's actions, as do Ribble (2016) and Roxin and Rusitoru (2016), who refer to the need for social awareness and concern for individual rights and responsibilities. Social etiquette, which is necessary for all social groups, even those that are online, is also considered a standard of conduct (Ribble, 2016) and is comparable to Hobbs (2010) identified need for making responsible choices with social actions. Park (2016) separates what she refers to as digital emotional intelligence from digital literacy in a broader conversation on digital skills. She refers to the need for an emotional awareness, self-regulation, and empathy for others. It is with an awareness and understanding of the role of ICT in a society, that individuals can balance their perceptions of, and actions with, ICT in society (Janssen et al., 2013). 
The seven digital learning domains (DLD's) described above, constitute the whole set of learning digital literacy competencies needed for learning at any age. In order to further validate the digital literacies inventory of 54 digital literacy skills developed by the research team, and test the study's theoretical model, it is necessary to examine the ties between each of the domains.

From the above, we drew the following research question: To what extent are the seven DLD's linked to each other?

\begin{tabular}{|c|c|c|c|c|c|c|c|c|c|}
\hline \multicolumn{10}{|c|}{$\begin{array}{c}\text { Digital Literacy Competencies } \\
\text { Catagorized using Kurtz and Peled's } 7 \text { Digital Learning Domains }\end{array}$} \\
\hline Information Research and Retrieval & & & & & & & & & $\mathrm{x}$ \\
\hline Articulate need & & & & & & & & & $\mathrm{x}$ \\
\hline Search; Access & $x$ & $\mathrm{x}$ & & & & $x$ & & & $\mathrm{x}$ \\
\hline Informed decisions on appropriate digital technologies & & & & & $x$ & & & & \\
\hline General knowledge and functional skills; Aquire & $\mathrm{x}$ & & & & $\mathrm{x}$ & & & & \\
\hline Information Validation & & & & & & & & & $\mathrm{x}$ \\
\hline Critical Thinking & $\mathrm{x}$ & & & $\mathrm{x}$ & & & $\mathrm{x}$ & & \\
\hline Computational thinking; Problem solving & & & & & & & $\mathrm{x}$ & $\mathrm{x}$ & \\
\hline Mindful reflection & $\mathrm{x}$ & & & $\mathrm{x}$ & & & & $\mathrm{x}$ & \\
\hline Analyze; Evaluate quality; Understand and reflect & $\mathrm{x}$ & $\mathrm{x}$ & & & & & & & $x$ \\
\hline Information Management & & & & & & & & & $\mathrm{x}$ \\
\hline Learning about and with digital techologies & & & & & $\mathrm{x}$ & & & & \\
\hline Use information in multuple formats in everyday life & $x$ & $\mathrm{x}$ & & & $x$ & & & & \\
\hline Seamless use demonstrating self-efficacy & $x$ & & & & $\mathrm{x}$ & & & & \\
\hline Information processing and management & & & & & $\mathrm{x}$ & & & & $\mathrm{x}$ \\
\hline Processing and Presentation of Information & & & & & & & & & $\mathrm{x}$ \\
\hline Content creation; Knowledge assembley & $\mathrm{x}$ & $\mathrm{x}$ & & & & & $x$ & & $\mathrm{x}$ \\
\hline Creative production of digital media & & & $\mathrm{x}$ & & & & & $\mathrm{x}$ & \\
\hline Specialized competence for creative expression & & & & & $\mathrm{x}$ & & & & $\mathrm{x}$ \\
\hline Information processing and management & & & & & $\mathrm{x}$ & $\mathrm{x}$ & & & \\
\hline Team-based Learning in Digital Environments & & & & & & & & & $\mathrm{x}$ \\
\hline Collaborative engagement; Social group construction & & & $\mathrm{x}$ & $\mathrm{x}$ & & & & & $\mathrm{x}$ \\
\hline Engage; Sharing; Pooling knowledge & & $x$ & & & & & & $\mathrm{x}$ & $x$ \\
\hline Digital co-creator & & & & & & & $\mathrm{x}$ & & \\
\hline Technology mediated communication and collaboration & & & & & $\mathrm{x}$ & & $\mathrm{x}$ & & \\
\hline Awareness of Digital Integrity & & & & & & & & & $\mathrm{x}$ \\
\hline Privacy and security & & & & & $\mathrm{x}$ & & $\mathrm{x}$ & & \\
\hline Legal and ethical aspects & $\mathrm{x}$ & $\mathrm{x}$ & & & $\mathrm{x}$ & & $\mathrm{x}$ & & $\mathrm{x}$ \\
\hline Social Responsibility & & & & & & & & & $\mathrm{x}$ \\
\hline Concern or individual rights, responsibilities, etiquette & & & & & & $\mathrm{x}$ & $\mathrm{x}$ & $\mathrm{x}$ & $\mathrm{x}$ \\
\hline Social action; Responsible choices & & $\mathrm{x}$ & & & & & $\mathrm{x}$ & & \\
\hline Balanced attitude towards technology & & & & & $\mathrm{x}$ & & & & \\
\hline Understanding and awareness of role of ICT in society & & & & & $\mathrm{x}$ & $\mathrm{x}$ & $\mathrm{x}$ & $\mathrm{x}$ & $\mathrm{x}$ \\
\hline
\end{tabular}

Figure 1 represents the many overlapping points outlined here and provides a visual reference for how the competencies described in the literature align with Kurtz and Peled (2016) digital learning domains (Shannon, 2017).. 


\begin{tabular}{|c|c|c|c|c|c|c|c|c|c|}
\hline \multicolumn{10}{|c|}{$\begin{array}{l}\text { Digital Literacy Competencies } \\
\text { Catagorized using Kurtz and Peled's } 7 \text { Digital Learning Domains }\end{array}$} \\
\hline Information Research and Retrieval & & & & & & & & & $\mathrm{x}$ \\
\hline Articulate need & & & & & & & & & $\mathrm{x}$ \\
\hline Search; Access & $\mathrm{x}$ & $\mathrm{x}$ & & & & $\mathrm{x}$ & & & $\mathrm{x}$ \\
\hline Informed decisions on appropriate digital technologies & & & & & $\mathrm{x}$ & & & & \\
\hline General knowledge and functional skills; Aquire & $\mathrm{x}$ & & & & $\mathrm{x}$ & & & & \\
\hline Information Validation & & & & & & & & & $\mathrm{x}$ \\
\hline Critical Thinking & $\bar{x}$ & & & $\mathrm{x}$ & & & $\mathrm{x}$ & & \\
\hline Computational thinking; Problem solving & & & & & & & $\mathrm{x}$ & $\mathrm{x}$ & \\
\hline Mindful reflection & $\mathrm{x}$ & & & $\mathrm{x}$ & & & & $\mathrm{x}$ & \\
\hline Analyze; Evaluate quality; Understand and reflect & $x$ & $\mathrm{x}$ & & & & & & & $\mathrm{x}$ \\
\hline Information Management & & & & & & & & & $\bar{x}$ \\
\hline Learning about and with digital techologies & & & & & $\mathrm{x}$ & & & & \\
\hline Use information in multuple formats in everyday life & $\mathrm{x}$ & $\mathrm{x}$ & & & $\mathrm{x}$ & & & & \\
\hline Seamless use demonstrating self-efficacy & $\mathrm{x}$ & & & & $\mathrm{x}$ & & & & \\
\hline Information processing and management & & & & & $\mathrm{x}$ & & & & $\mathrm{x}$ \\
\hline Processing and Presentation of Information & & & & & & & & & $\mathrm{x}$ \\
\hline Content creation; Knowledge assembley & $\mathrm{x}$ & $\mathrm{x}$ & & & & & $\mathrm{x}$ & & $\mathrm{x}$ \\
\hline Creative production of digital media & & & $\mathrm{x}$ & & & & & $\mathrm{x}$ & \\
\hline Specialized competence for creative expression & & & & & $\mathrm{x}$ & & & & $\mathrm{x}$ \\
\hline Information processing and management & & & & & $\mathrm{x}$ & $\mathrm{x}$ & & & \\
\hline Team-based Learning in Digital Environments & & & & & & & & & $\mathrm{x}$ \\
\hline Collaborative engagement; Social group construction & & & $\mathrm{x}$ & $\mathrm{x}$ & & & & & $\mathrm{x}$ \\
\hline Engage; Sharing; Pooling knowledge & & $\mathrm{x}$ & & & & & & $\mathrm{x}$ & $\mathrm{x}$ \\
\hline Digital co-creator & & & & & & & $\mathrm{x}$ & & \\
\hline Technology mediated communication and collaboration & & & & & $\mathrm{x}$ & & $\mathrm{x}$ & & \\
\hline Awareness of Digital Integrity & & & & & & & & & $\mathrm{x}$ \\
\hline Privacy and security & & & & & $\mathrm{x}$ & & $\mathrm{x}$ & & \\
\hline Legal and ethical aspects & $\mathrm{x}$ & $\mathrm{x}$ & & & $\mathrm{x}$ & & $\mathrm{x}$ & & $\mathrm{x}$ \\
\hline Social Responsibility & & & & & & & & & $\mathrm{x}$ \\
\hline Concern or individual rights, responsibilities, etiquette & & & & & & $\mathrm{x}$ & $\mathrm{x}$ & $\mathrm{x}$ & $\bar{x}$ \\
\hline Social action; Responsible choices & & $\mathrm{x}$ & & & & & $x$ & & \\
\hline Balanced attitude towards technology & & & & & $\mathrm{x}$ & & & & \\
\hline Understanding and awareness of role of ICT in society & & & & & $\mathrm{x}$ & $\mathrm{x}$ & $\mathrm{x}$ & $\mathrm{x}$ & $x$ \\
\hline
\end{tabular}

Figure 1: DL Competencies: Categorized by Kurtz and Peled's seven DLD's Conceptual Model and Hypotheses (Shannon, 2017).

\section{Method}

\subsection{Purpose of the research}

In light of the above, the main purpose of the current research was to gather empirical evidence regarding the firmness of a digital literacies inventory of 54 digital literacy skills developed by the research team, and test the study's theoretical model.

The validation presented in this study is based on the digital literacy competencies of pre-service Israeli teachers (Peled, 2020) and didacts their digital readiness. The purpose of this deduction was to assess the degree to which Israeli pre-service teachers are ready to prepare and lead their students into the digital world.

\subsection{Development of the research instrument}


The research instrument - The Self-Report Digital Literacies (SRDL) was initially developed by Kurtz and Peled (2016) in a two phase process:

- $\quad$ Phase 1 - compilation of PS's and DLD's which yielded 64 PS's.

- $\quad$ Phase 2 - validation of the 64 PS's left 54 valid PS's.

Phase 1 - was based on an exhaustive literature research, a list of DLD's and PS's was compiled (see table 1) and distributed for pre-validation review and comments to six expert researchers in the educational technology field, and to seven graduate students of ICT studying at the College of Academic Studies in Israel. The experts and the students were asked to provide a critical review of the DLD's and PS's. More specifically, they were requested to respond to open-ended questions concerning the fitness, appropriateness, missing items, revision, rephrasing, and clarity of the items. Their comments were analysed by the research team to determine what revisions of the DLD's (if any) were to be included in the survey. Based on respondent input, a final set of seven DLD and sixty-five Likert-type scale items from 1 to 5 was listed. The 64-item survey was administered to 1,889 students at the Western Galilee College in Israel. The analysis of the data showed that 10 items had low compatibility and were accordingly excluded (see appendix 2 ).

Table 1: Origin of Domains

\begin{tabular}{|c|c|c|}
\hline Domain & Literacy & Source \\
\hline Information Collection & $\begin{array}{l}\text { The ability to recognize information needs, access, } \\
\text { understand and use effectively and efficiently } \\
\text { information using Internet, professional organization } \\
\text { databases and search engines }\end{array}$ & $\begin{array}{l}\text { (Ala-Mutka, 2011; Chandra, } \\
\text { 2013; Lau and Yuen, 2014; } \\
\text { Lester, 1995; Mioduser et al., } \\
\text { 2008; Nelson et al., 2011) }\end{array}$ \\
\hline Information Evaluation & $\begin{array}{l}\text { The ability to evaluate the quality, reliability, } \\
\text { relevance, timeliness, completeness, credibility, } \\
\text { usefulness, and efficiency of digital resources }\end{array}$ & $\begin{array}{l}\text { (Brouwer, 1996; Eshet-Alkali } \\
\text { and Amichai-Hamburger, } \\
\text { 2004; Henry, 2005; Lau and } \\
\text { Yuen, 2014; Nelson et al., } \\
\text { 2011) }\end{array}$ \\
\hline \multirow[t]{2}{*}{ Information Management } & $\begin{array}{l}\text { The ability to save, retrieve and to tag digital } \\
\text { information while including knowledge about } \\
\text { copyright and plagiarism issues }\end{array}$ & $\begin{array}{l}\text { (Dudeney et al., 2014; } \\
\text { Mioduser et al., 2008; Nelson } \\
\text { et al., 2011) }\end{array}$ \\
\hline & $\begin{array}{l}\text { The ability to protect personal data and information } \\
\text { from threats such as unauthorized access, } \\
\text { destruction, identity theft, impersonation, } \\
\text { unauthorized alteration of data, or fictitious creation }\end{array}$ & $\begin{array}{l}\text { (Lau and Yuen, 2014; Nelson } \\
\text { et al., 2011) }\end{array}$ \\
\hline Information Processing & $\begin{array}{l}\text { The ability to use ICT to design or create new } \\
\text { information from information already acquired }\end{array}$ & (Lau and Yuen, 2014) \\
\hline Teamwork & $\begin{array}{l}\text { The ability to work with others (instructor and peers) } \\
\text { toward a common intended learning goal through, } \\
\text { discourse, collaboration, cooperation, RBL and PBL }\end{array}$ & $\begin{array}{l}\text { (Harasim, 2012; Henry, 2005; } \\
\text { Jung and Latchem, 2011; } \\
\text { Nelson et al., 2011; Panitz, } \\
\text { 1999) }\end{array}$ \\
\hline Integrity Awareness & Maintain digital integrity \& ethical standards & \\
\hline Social Responsibility & $\begin{array}{l}\text { Understanding the social and ethical implications/ } \\
\text { consequences of the use of digital resources }\end{array}$ & (Nelson et al., 2011) \\
\hline
\end{tabular}

Phase 2 - The remaining 54 PS's were retested for reliability showing a relatively high Cronbach's alpha values as it can be attested in table 3 . The current report relates to phase 2 of the research.

The seven domains and the number of statements pertaining to each domain can be seen in Table 2 .

Table 2: The seven domains and the number of statements pertaining to each domain

\begin{tabular}{|l|c|l|}
\hline \multicolumn{1}{|c|}{ Domain } & \# of statements & \multicolumn{1}{c|}{ Refers to questions such as: } \\
\hline Information collection & 12 & $\begin{array}{l}\text { objectively search effectively; how to distinguish } \\
\text { between different types of search, sources, and } \\
\text { information }\end{array}$ \\
\hline Information evaluation & 5 & $\begin{array}{l}\text { judging the information gathered and assessing its } \\
\text { credibility }\end{array}$ \\
\hline Information management & 3 & personal storage for posterior retrieval \\
\hline Information processing & 8 & $\begin{array}{l}\text { assessing, interpreting, analysing and synthesizing } \\
\text { information from multiple sources for later usage }\end{array}$ \\
\hline Teamwork & 8 & participation levels of different peers in a studying task \\
\hline
\end{tabular}




\begin{tabular}{|l|c|l|}
\hline \multicolumn{1}{|c|}{ Domain } & \# of statements & \multicolumn{1}{c|}{ Refers to questions such as: } \\
\hline Integrity awareness & 15 & $\begin{array}{l}\text { concern of ethical, moral, and social consequences of } \\
\text { usage, or mis-usage, of digital information }\end{array}$ \\
\hline Social responsibility & 3 & proper behaviour in the social digital environment \\
\hline
\end{tabular}

(All items were assigned a 5-point Likert scale from 1 (not at all) to 5 (to a very large extent).

A further evaluation of students' digital readiness is based on Horrigan's (2016) work. For the purpose of this study, we categorized the original seven domains of the digital literacy questionnaire (Kurtz and Peled, 2016) into four types of digital readiness: (a) basic order readiness (information collection, information processing); (b) advanced order readiness (information management, information evaluation); (c) preparedness for teamwork (teamwork); and (d) ethical readiness (integrity awareness, social responsibility). The background characteristics of the participants are examined using the following questions: (a) school of study; (b) degree; (c) gender; (d) age; and (e) sense of control of Internet technologies.

\subsection{Procedure/Information Collection and Participants}

We used an online questionnaire to anonymously collect information from five teachers' colleges/colleges of education in the north, centre, and south of Israel. The recruitment was done with the assistance of the different institution's managements, which sent the questionnaires, via email, to their students. The information collection was carried out from the spring of 2015 to the spring of 2017.

\subsubsection{Participants}

A total of 1,265 undergraduate pre-service teachers and in-service teachers, studying for their graduate degree, completed an online questionnaire. Four hundred and eighty-one students (38.0\%) were from college A, 375 (29.6\%) from college B, 165 (13\%) from college C, 133 (10.5\%) from college D and 90 (7.1\%) from college E. Twenty-one students (1.8\%) did not identify their college. The overall response rate was $25.9 \%$, with the individual rates varying as follows: $37.2 \%$ (college A), $75 \%$ (college B), $16.5 \%$ (college C), $4 \%$ (college D) and $16.6 \%$ (college E); $57.5 \%$ were undergraduate students and $38.5 \%$ were graduate students. Most of the respondents (79\%) were women. The average age was 33.4 years $(S D=10.4 ; M=32)$.

\subsection{Data Analysis}

The data was analysed in two stages.

In the first stage, the internal consistency (reliability) of the questionnaire was explored (Table 3). In the second stage, structural equation modelling (SEM) was used to conduct a path analysis that tested the study's theoretical model.

Table 3: Internal consistency (reliability) of the Questionnaire

\begin{tabular}{clll}
\hline Name & Number of items & Cronbach's alpha \\
\hline A. & Information Collection & 12 & .939 \\
B. Information Evaluation & 5 & .885 \\
C. Information Management & 3 & .758 \\
D. Information Processing & 8 & .917 \\
E. Teamwork & 8 & .911 \\
F. Integrity Awareness & 15 & .934 \\
G. Social Responsibility & 3 & .888 \\
\hline
\end{tabular}

\section{Results}

The interactions between the seven DLD's were evaluated with structural equation modelling through AMOS 25.0 software.

For this analysis, responders which one of the variables were not calculated for them were excluded from the analysis, as were respondents who did not specify their gender or level of education. In total, the sample included 950 respondents.

\subsection{Model analysis}


Full information maximum likelihood estimates were computed by means of the Analysis of Moment Structures (AMOS) program (Arbuckle and Wothke, 1999). Structural models linking Information Collection, Information Evaluation, Information Management, Information Processing, Teamwork, Integrity Awareness and Social Responsibility were tested, the results of which are summarized in Figure 2. The model was examined for goodness of fit using $\chi 2$, comparative fit index (CFI) and root mean square error of approximation (RMSEA) fit indices. CFI values above .90 and .95 indicate adequate and good model fit, respectively, and RMSEA values below .08 and .05 indicate adequate and good model fit, respectively (Browne and Cudeck, 1992; Hu and Bentler, 1999; Kline, 2015) (see Table 4). According to Awang (2012), it is customary to use three sets of estimations for level of compatibility: absolute compatibility ( $\left.\chi^{2}, \mathrm{RMSEA}, \mathrm{PClose}\right)$, incremental (NFI, TLI, CFI) and parsimonious $\left(\chi^{2} / \mathrm{df}\right)$.

The first stage of the estimation was to examine the extent to which the model is compatible with the data using the maximum-likelihood (ML) model.

Table 4: Fit measures of the proposed research models testing the relations between Information Collection, Information Evaluation, Information Management, Information Processing, Teamwork, Integrity Awareness and Social Responsibility for the entire sample $(\mathrm{N}=950)$

\begin{tabular}{|c|c|c|c|}
\hline Fit measures & & Recommended levels of fit (Awang, 2012) & Value of the measure \\
\hline & $\chi^{2}$ & n.s. at $p<.05$ & $6.918_{(d f=3)}, p>.05$ \\
\hline \multirow[t]{3}{*}{$\begin{array}{l}\text { Absolute } \\
\text { Fit }\end{array}$} & RMSEA & $<.08$ & .037 \\
\hline & PCLOSE & $>.05$ & .664 \\
\hline & CFI & $>.90$ & .999 \\
\hline \multirow[t]{2}{*}{$\begin{array}{l}\text { Incremental } \\
\text { Fit }\end{array}$} & TLI & $>.90$ & .993 \\
\hline & $\mathrm{NFI}$ & $>.90$ & .998 \\
\hline $\begin{array}{l}\text { Parsimonious } \\
\text { Fit }\end{array}$ & $\chi^{2} / d f$ & $<3.0$ & 2.306 \\
\hline
\end{tabular}

The results detailed in Table 5 indicate a good correlation between the proposed research model and the data. The second stage in the analysis of structural equations includes an assessment of the interactions between the variables using a path analysis model. In general, the evaluation of a structural equation model allows us to examine the quality of fit for a model between two types of variables: exogenous variables, that are independent variables unrelated to other variables in the model, and endogenous variables associated with other variables in the model. In the current model, there are no exogenous variables, and all of the variables are endogenous, while they may be related to each other. Figure 2 displays the standardized effect coefficients $(\beta)$ of the dimensions and the explained variance rate (R2), and accordingly, Table 5 includes a breakdown of the aggregate cumulative effect $(\beta)$ among the variables in the study. The model shows that the size of the effect, as can be seen from the level of explanation of the variance of the variables in the model, is high (R2>.25 for all the variables) (Cohen, 1992). 


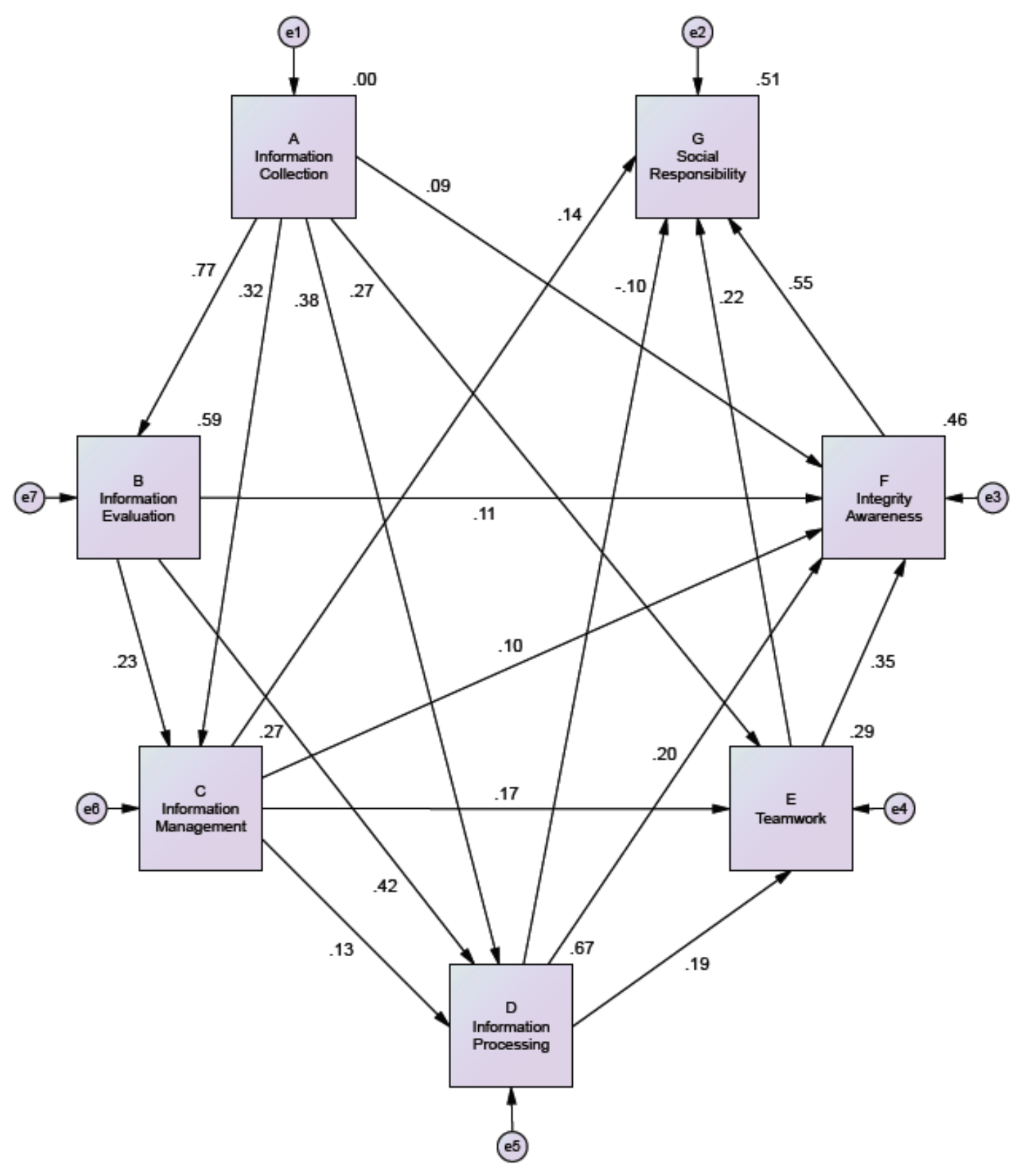

Figure 2: Path analysis for the proposed research models testing the relations between Information Collection, Information Evaluation, Information Management, Information Processing, Teamwork, Integrity Awareness and Social Responsibility for the entire sample $(\mathrm{N}=950)$.

The analysis (Figure 2) shows that most of the variables are directly related apart from a non-direct effect between Information Collection (A) and Social Responsibility (G) and between Information Evaluation (B) and Teamwork (E) and Social Responsibility (G). The interaction between the variables is only indirect. Furthermore, analysis of the direct effects between the variables shows that all of them are positive; that is, the correlation between the variables is positive. An exception to this rule is the connection between Information Processing (D) and Social Responsibility (G) ( $\beta=-.10)$, which indicates a negative correlation between the two variables, even though, as can be seen from Table, the connection between Information Processing (D) and Social Responsibility $(G)$ is positive but low $(\beta=.09)$. 
Table 5: Standardized total effects for the proposed research models testing the relations between Information Collection, Information Evaluation, Information Management, Information Processing, Teamwork, Integrity Awareness and Social Responsibility for the entire sample ( $\mathrm{N}=950)$

\begin{tabular}{|c|c|c|c|c|c|c|}
\hline & A & B & C & D & $E$ & $\mathrm{~F}$ \\
\hline & $\begin{array}{l}\text { Information } \\
\text { Collection }\end{array}$ & $\begin{array}{l}\text { Information } \\
\text { Evaluation }\end{array}$ & $\begin{array}{l}\text { Information } \\
\text { Management }\end{array}$ & $\begin{array}{l}\text { Information } \\
\text { Processing }\end{array}$ & Teamwork & $\begin{array}{l}\text { Integrity } \\
\text { Awareness }\end{array}$ \\
\hline $\begin{array}{l}\text { Information } \\
\text { Evaluation }\end{array}$ & 0.77 & & & & & \\
\hline $\begin{array}{l}\text { Information } \\
\text { Management }\end{array}$ & 0.50 & 0.23 & & & & \\
\hline $\begin{array}{l}\text { Information } \\
\text { Processing }\end{array}$ & 0.76 & 0.45 & 0.13 & & & \\
\hline Teamwork & 0.50 & 0.12 & 0.19 & 0.19 & & \\
\hline $\begin{array}{l}\text { Integrity } \\
\text { Awareness }\end{array}$ & 0.55 & 0.26 & 0.19 & 0.26 & 0.35 & \\
\hline $\begin{array}{l}\text { Social } \\
\text { Responsibility }\end{array}$ & 0.41 & 0.16 & 0.28 & 0.09 & 0.41 & 0.55 \\
\hline
\end{tabular}

The results of the analysis indicate the existence of a multi-layered model where all the variables are affected by the variables at the lower levels. Within this framework:

- The variable Information Collection (A) has a direct effect on the variable Information Evaluation (B) $(\beta=.77)$.

- The variable Information Management (C) is affected directly by Information Evaluation (B), which is at the second level $(\beta=.23)$ but also positively by the variable at the first level Information Collection $(A)$, directly $(\beta=.32)$ but also through the effect of the variable Information Evaluation $(B)$ on the variable Information Management (C) such as the overall effect is $\beta=.50$.

- The variable Information Processing (D) is directly influenced from the variable Information Management $(C)(\beta=.13)$, which is at the previous level and is positively affected, directly and indirectly, from the variables at previous levels: Information Collection (A) $(\beta=.76)$ and Information Evaluation (B) $(\beta=.45)$.

- The variable Teamwork (E) is directly affected by the variable Information Processing (D) $(\beta=.19)$ at the previous level, and is positively influenced from the variables at previous levels: directly and indirectly from the variable Information Collection $(A)(\beta=.50)$ : only indirectly from the variable Information Evaluation $(B)(\beta=.12)$ and directly and indirectly from the variable Information Management $(C)(\beta=.19)$.

- $\quad$ The variable Integrity Awareness (F) is positively affected by the variable at the previous level Teamwork (E) $(\beta=.35)$, and is directly and indirectly affected by the variable Information Collection (A) $(\beta=.55)$; directly and indirectly from the variable Information Evaluation $(B)(\beta=.26)$; directly and indirectly from the variable Information Management $(C)(\beta=.19)$ and directly and indirectly from the variable Information Processing $(\beta=.26)$.

- The variable Social Responsibility (G) at the highest level is positively and directly affected by the variable at its previous level Integrity Awareness (F) $(\beta=.55)$. Also, this variable is only indirectly affected by the variables Information Collection $(A)(\beta=.41)$ and Information Evaluation $(B)(\beta=.16)$.

- The variable Social Responsibility $(G)$ is directly and indirectly affected by the variable Information Management $(C)(\beta=.28)$ and directly and indirectly from the variable Teamwork (E) $(\beta=.41)$.

- As noted above, despite the direct and negative effect of the variable Information Processing (D) ( $\beta=-$ .10), the overall effect of this variable on the variable Social Responsibility (G) is completely balanced by the indirect effect, so that in the end, this effect is positive, even if it is low $(\beta=.09)$. 
From the analysis, it appears that at the basis of the multi-level model is the variable Information Collection (A) on variables at higher levels. Also, it was found that the three "old world" variables are based on Teamwork (E), Integrity Awareness (F) and the effect of these to variables on Social Responsibility (G).

\section{Conclusions, implications, and limitations}

The main purpose of the current research was to gather empirical evidence regarding the firmness of a digital literacies inventory of 54 digital literacy skills developed by the research team. This is a second phase; while in the first phase an inventory of 64 digital literacy skills were evaluated and validated (Kurtz and Peled, 2016), in the second phase a further reduction to the digital skills was done; thus finally a set of 54 digital literacy skills represents the seven DLD's. This inventory was initially built based upon an extensive review of the literature, along with an examination of definitions, concepts, case studies and theoretical models that deal with the 21st century digital skills required for learning.

The results of the analysis indicate the existence of a multi-layered model, where all of the variables are affected by the variables at the lower levels, meaning that the model elements which are the different DLD's are positively connected to each other. Thus, our findings suggest a strong statistical validation of the inventory. The connection between the DLD's, as the model indicates, show that the initial process of which the DLD's were determined was correct, and that the DLD's representing the sphere of digital literacy do represent that sphere of competences.

As there is a research gap on pre-service teacher's digital literacy perception, usage, and posterior readiness to include digital environments in the transfer of subject knowledge (Peled, 2020) the proposed inventory can serve as a valid and strong instrument by which pre-service teachers' digital readiness can be measured. The findings show a distinction between the types of preparedness that have developed in the digital sphere and those that existed in the pre-digital sphere: of the four types of digital readiness: (a) basic order readiness (information collection, information processing); (b) advanced order readiness (information management, information evaluation); (c) preparedness for teamwork (teamwork); and (d) ethical readiness (integrity awareness, social responsibility) students report a high level of readiness for teamwork and ethical conduct relevant to both offline and online environments. On the other hand, the participants reported a medium to low level of preparedness for the types of preparedness relevant to an online environment only: readiness of a basic and advanced order. These findings point to the fact that pre-service teachers are in a transit phase from digital immigrants to digital natives (Prensky 2001).

As "The Israeli National ICT Programme" aims to promote innovative pedagogy in schools by encouraging teachers to intelligently integrate content worlds, books, tools, and digital environments into teaching, learning and evaluation processes. The programme develops technological and digital literacy through a broad and rich array of projects, online activities and alternative learning frameworks (Ministry of Education, 2018). Thus, the digital literacies inventory for measuring digital literacy, which was found to be reliable, can be used to assess teachers' ability to teach in the manner mentioned above by the Israeli Ministry of Education and achieve its objectives.

An international implication of the study is that as reported by UNESCO's Recommendations on Assessment Tools for Monitoring Digital Literacy within Digital Literacy Global Framework (Laanpere, 2019) which reviewed 44 different digital literacy skills assessment instruments and could not recommend a suitable solution for the UNESCO Institute for Statistics, contrary to that, the digital literacies inventory offer a robust assessment instrument which can be used internationally in any educational context (the inventory have been tested in 9 different countries in Europe, U.S.A., Asia, Middle East, and some countries in the Far-East - ongoing research).

The digital literacies inventory for measuring digital literacy can be used to assess students' digital readiness on a regular basis, thereby enabling the various levels at school to adjust the teaching materials and pedagogy to achieve the required level of digital readiness defined by the school.

Additional research is needed in order to shed more light on some of the connections between the various domains. For instance, the connection between Information Processing and Social Responsibility indicates a negative correlation between the two variables, even though the connection between them is positive but low. 
Statements on open data, ethics, and conflict of interest:

1. The data cannot be accessed as it is not stored online.

2. A permission was granted to carry-out this research by the IRB of the Western Galilee College, Israel.

3. There is no conflict of interest in the work we are reporting here.

4. This research did not receive any specific grant from funding agencies in the public, commercial, or notfor-profit sectors.

\section{References}

Akayoglu, S., Satar, H.M., Dikilitas, K., Cirit, N.C. and Korkmazgil, S., 2020. Digital literacy practices of Turkish pre-service EFL teachers. Australasian Journal of Educational Technology, 36(1), pp.85-97.

Ala-Mutka, K., 2011. Mapping digital competence: Towards a conceptual understanding. Sevilla: Institute for Prospective Technological Studies, pp.7-60.

Arbuckle, J.L. and Wothke, W., 1999. Amos 4.0 user's guide. Chicago, IL: SmallWaters Corporation.

Ata, R. and Yıldırım, K., 2019. Exploring Turkish pre-service teachers' perceptions and views of digital literacy. Education Sciences, 9(1), p.40.

Awang, Z., 2012. A handbook on structural equation modeling using AMOS. Universiti Technologi MARA Press, Malaysia.

Baller, S., Dutta, S. and Lanvin, B., 2016. Global information technology report 2016. Geneva: Ouranos.

Bawden, D., 2001. Information and digital literacies: a review of concepts. Journal of Documentation, 57(2), pp.218-259.

Binkley, M., Erstad, O., Herman, J., Raizen, S., Ripley, M., Miller-Ricci, M. and Rumble, M., 2012. Defining twenty-first century skills. In: P. Griffin, B. McGaw, E. Care (eds) Assessment and teaching of 21st century skills (pp. 17-66). Dordrecht; Springer. https://doi.org/10.1007/978-94-007-2324-5_2

Bishop J., 2015. Partnership for 21st Century Skills (P21). [online] Available at: <https://www.imls.gov/assets/1/AssetManager/Bishop\%20Pre-Con\%202.pdf>. [Accessed 19 November 2020].

Boh Podgornik, B., Dolničar, D., Šorgo, A. and Bartol, T., 2016. Development, testing, and validation of an information literacy test (ILT) for higher education. Journal of the Association for Information Science and Technology, 67(10), pp.2420-2436.

Brouwer, P., 1996. Hold on a minute here: what happened to critical thinking in the information age?. Journal of Educational Technology Systems, 25(2), pp.189-197. https://doi.org/10.2190/gjl2-a890-0n9w-7frd

Browne, M.W. and Cudeck, R., 1992. Alternative ways of assessing model fit. Sociological Methods \& Research, 21(2), pp.230-258. https://doi.org/10.1177/0049124192021002005

Chandra, S., 2013. Towards information literacy. Asian Journal of Social Sciences, Arts and Humanities 1(1), pp.1-4.

Chetty, K., Qigui, L., Gcora, N., Josie, J., Wenwei, L. and Fang, C., 2018. Bridging the digital divide: measuring digital literacy. Economics: The Open-Access, Open-Assessment E-Journal, 12(2018-23), pp.1-20.

Cohen, J., 1992. A power primer. Psychological Bulletin, 112(1), p.155.

Covello, S. and Lei, J., 2010. A review of digital literacy assessment instruments. USA: Syracuse University, pp.1-31.

Dede, C., 2010. Comparing frameworks for 21st century skills. 21st century skills: Rethinking How Students Learn, 20(2010), pp.51-76.

Hockly, N., Dudeney, G. and Pegrum, M., 2014. Digital literacies. London:.Routledge.

Alkali, Y.E. and Amichai-Hamburger, Y., 2004. Experiments in digital literacy. CyberPsychology \& Behavior, 7(4), pp.421-429. https://doi.org/10.1089/cpb.2004.7.421

Fraenkel, J.R., Wallen, N.E. and Hyun, H.H., 1993. How to design and evaluate research in education (Vol. 7). New York: McGraw-Hill.

Gilster, P., 1997. Digital Literacy. New York: Wiley\&Sons.

Güneş, E. and Bahçivan, E., 2018. A mixed research-based model for pre-service science teachers' digital literacy: responses to "which beliefs" and "how and why they interact" questions. Computers \& Education, 118, pp.96-106. DOI:10.1016/i.compedu.2017.11.012

Harasim, L., 2012. Learning theory and online technologies, Learning Theory and Online Technologies. London: Routledge. https://doi.org/10.4324/9780203846933

Henry, J., 2005. Confronting the challenges of participatory culture: Media education for the 21st century. Cambridge, Mass: MIT Press.

Hibberson, S., Barrett, E., Davies, S., 2015. Developing students' digital literacy. [online] Available at: < https://www.jisc.ac.uk/guides/developing-students-digital-literacy >. [Accessed 19 November 2020].

Hobbs, R., 2010. Digital and media literacy: A plan of action. A white paper on the digital and media literacy recommendations of the knight commission on the information needs of communities in a democracy. Aspen Institute. [online] Available at: <https://eric.ed.gov/?id=ED523244>. [Accessed 29 November 2020].

Horrigan, J.B., 2016. Digital readiness gaps. Pew Research Center. [online] Available at: <https://www.pewresearch.org/internet/2016/09/20/digital-readiness-gaps/>. [Accessed 19 November 2020].

Hsu, S., 2010. Developing a scale for teacher integration of information and communication technology in grades 19. Journal of Computer Assisted Learning, 26(3), pp.175-189.

Hu, L.T. and Bentler, P.M., 1999. Cutoff criteria for fit indexes in covariance structure analysis: Conventional criteria versus new alternatives. Structural Equation Modeling: A Multidisciplinary Journal, 6(1), pp.1-55. 
Janssen, J., Stoyanov, S., Ferrari, A., Punie, Y., Pannekeet, K. and Sloep, P., 2013. Experts' views on digital competence: commonalities and differences. Computers \& Education, 68, pp.473-481.

Jenkins, H., Clinton, K., Purushotma, R., Robison, A.J. and Weigel, M., 2006. Confronting the challenges of participatory culture: media education for the 21st century. MacArthur Foundation. p.2008. [online] Available at: <https://www.macfound.org/media/article_pdfs/jenkins_white_paper.pdf>. [Accessed 19 November 2020].

Jung, I. and Latchem, C., 2011. A model for e-education: extended teaching spaces and extended learning spaces. British Journal of Educational Technology, 42(1), pp.6-18. https://doi.org/10.1111/j.1467-8535.2009.00987.x

Kline, R.B., 2015. Principles and practice of structural equation modeling. London; New York: Guilford publications, p. 354.

Kuek, A. and Hakkennes, S., 2020. Healthcare staff digital literacy levels and their attitudes towards information systems. Health Informatics Journal, 26(1), pp.592-612.

Kurbanoglu, S.S., Akkoyunlu, B. and Umay, A., 2006. Developing the information literacy self-efficacy scale. Journal of Documentation, 62(6), pp.730-743. DOI: 10.1108/00220410610714949

Kurtz, G. and Peled, Y., 2016. Digital learning literacies-a validation study. Issues in Informing Science \& Information Technology, 13, pp.145-158. https://doi.org/10.28945/3479.

Laanpere, M., 2019. Recommendations on assessment tools for monitoring digital literacy within unesco's digital literacy global framework. Information Paper No. 56. [online] Available at: $<$ http://uis.unesco.org/sites/default/files/documents/ip56-recommendations-assessment-tools-digital-literacy-2019en.pdf>. [Accessed 19 November 2020].

Lau, W.W.F., Yuen, A.H.K., 2014. Developing and validating of a perceived ICT literacy scale for junior secondary school students: Pedagogical and educational contributions. Computers and Education 78, pp.1-9. https://doi.org/10.1016/j.compedu.2014.04.016

Lester, P.M., 1995. Digital literacy: Visual communication and computer images. ACM SIGGRAPH Computer Graphics, 29(4), pp.25-27. https://doi.org/10.1145/216876.216882

Literat, I., 2014. Measuring new media literacies: towards the development of a comprehensive assessment tool. Journal of Media Literacy Education, 6(1), pp.15-27.

Lyons, A., Kass-Hanna, J., Zucchetti, A. and Cobo, C., 2019. Leaving no one behind: measuring the multidimensionality of digital literacy in the age of $A$ l and other transformative technologies. online] Available at: <https://t20japan.org/policy-brief-multidimensionality-digital-literacy/>. [Accessed 22 November 2020]

Mills, K.A., 2010. A review of the "digital turn" in the new literacy studies. Review of Educational Research, 80(2), pp.246271.

Ministry of Education., 2018. Creating necessary frameworks to promote science and technology [online] Available at: $<$ https://sites.education.gov.il/cloud/home/tikshuv/Pages/tikshuv.aspx>. [Accessed 19 November 2020]. [Hebrew]

Mioduser, D., Nachmias, R. and Forkosh-Baruch, A., 2008. New literacies for the knowledge society. In: J. Voogt, G. Knezek (eds). International handbook of information technology in primary and secondary education (pp. 23-42). Springer: Boston, MA. https://doi.org/10.1007/978-0-387-73315-9_2

Nelson, K., Courier, M. and Joseph, G.W., 2011. An investigation of digital literacy needs of students. Journal of Information Systems Education, 22(2), pp.95-110.

Panitz, T., 1999. The case for student centered instruction via collaborative learning paradigms. ERIC ED448444. [online] Available at: <https://files.eric.ed.gov/fulltext/ED448444.pdf>. [Accessed 19 November 2020].

Park, Y., 2016. 8 digital skills we must teach our children. In: World Economic Forum. [online] Available at: $<$ https://www.weforum.org/agenda/2016/06/8-digital-skills-we-must-teach-our-children/>. [Accessed 20 November 2020].

Peled, Y., 2020. Pre-service teacher's self-perception of digital literacy: the case of Israel. Education and Information Technologies, pp.1-18. https://doi.org/10.1007/s10639-020-10387-x.

Perdana, R., Riwayani, R., Jumadi, J. and Rosana, D., 2019a. Development, reliability, and validity of open-ended test to measure student's digital literacy skill. International Journal of Educational Research Review, 4(4), pp.504-516.

Perdana, R., Yani, R., Jumadi, J., Rosana, D., 2019b. Assessing students' digital literacy skill in senior high school yogyakarta. Jurnal Pendidikan Indonesia 8(2). http://dx.doi.org/10.23887/jpi-undiksha.v8i2.17168

Porat, E., Blau, I. and Barak, A., 2018. Measuring digital literacies: junior high-school students' perceived competencies versus actual performance. Computers \& Education, 126, pp.23-36. https://doi.org/10.1016/j.compedu.2018.06.030

Prensky, M., 2001. Digital natives, digital immigrants. On the Horizon, 9(5). doi:10.1108/10748120110424816

Promsri, C., 2019. The association between digital literacy and social intelligence. International Journal of English Literature and Social Sciences (IJELS), 4(4), pp.1069-1072. DOI: 10.22161/ijels.4423

Rheingold, H., 2012. Net smart: How to thrive online. Cambridge, MA: MIT Press.

Ribble, M., 2016. Nine themes of digital citizenship. [online] Available at: <http://www.digitalcitizenship.net/Nine_Elements.html>. [Accessed 20 November 2020].

Rodríguez-de-Dios, I., Igartua, J.J. and González-Vázquez, A., 2016, November. Development and validation of a digital literacy scale for teenagers. In Proceedings of the fourth international conference on technological ecosystems for enhancing multiculturality (pp. 1067-1072).

Roxin, I., Rusitoru, M.V., 2016. Digital literacy for the emerging educational resources in the context of lifelong learning, In: Proceedings of the international conference on education and new developments. Ljubljana, Slovenia. (pp.359-364). [online] Available at: <https://files.eric.ed.gov/fulltext/ED578322.pdf>. [Accessed 20 November 2020]. 
Shannon, S.K., 2017. A mixed methods exploratory study of tal literacies in higher education. Boise State University Theses and Dissertations 1357. https:// Digidoi.org/10.18122/B2F71F

Siddiq, F., Gochyyev, P. and Wilson, M., 2017. Learning in digital networks-ict literacy: a novel assessment of students' 21st century skills. Computers \& Education, 109, pp.11-37. https://doi.org/10.1016/j.compedu.2017.01.014

Siddiq, F., Hatlevik, O.E., Olsen, R.V., Throndsen, I. and Scherer, R., 2016. Taking a future perspective by learning from the past-A systematic review of assessment instruments that aim to measure primary and secondary school students' ICT literacy. Educational Research Review, 19, pp.58-84.

Šorgo, A., Bartol, T., Dolničar, D. and Boh Podgornik, B., 2017. Attributes of digital natives as predictors of information literacy in higher education. British Journal of Educational Technology, 48(3), pp.749-767.

Tondeur, J., Aesaert, K., Pynoo, B., van Braak, J., Fraeyman, N. and Erstad, O., 2017. Developing a validated instrument to measure preservice teachers' ICT competencies: meeting the demands of the 21st century. British Journal of Educational Technology, 48(2), pp.462-472.

Tyger, R.L., 2011. Teacher candidates' digital literacy and their technology integration efficacy. Electronic Theses and Dissertations. 557. https://digitalcommons.georgiasouthern.edu/etd/557

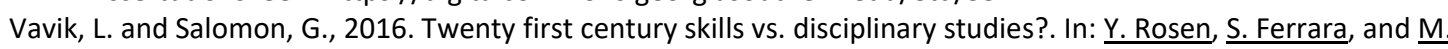
Mosharraf. Handbook of research on technology tools for real-world skill development pp.1-12. Hershey Pennsylvania: IGI Global. DOI: 10.4018/978-1-4666-9441-5.ch001.

Watt, D., 2019. Video production in elementary teacher education as a critical digital literacy practice. Media and Communication, 7(2), pp.82-99.

Yang, S., 2019. Developing an assessment framework: Measuring digital literacy of interior design students in a digital drawing course. Theses and Dissertations. 1063. http://doi.org/10.30707/ETD2019.Yang.S

\section{Appendices}

Appendix 1: Digital literacies survey

Instructions: This questionnaire is designed to learn about your digital literacies by using the following scale: 1 . Strongly disagree; 2 . Somewhat disagree 3. Neither disagree nor agree; 4. Somewhat agree; 5. Strongly agree. 1. Data Collection

\begin{tabular}{|ll|}
\hline 1. I know when I need to look for information \\
\hline 2. & I am able to identify information for research \\
\hline 3. & I am able to collect information from the web \\
\hline 4. & I can define the objective of the search \\
\hline 5. & I can articulate what information I need \\
\hline 6. & I know how to search effectively \\
\hline 7. & I can define research terms \\
\hline 8. & I can distinguish between types of search \\
\hline 9. & I can retrieve information from various sources \\
\hline 10. I am able to collect information from databases \\
\hline 11. I am able to re-locate information \\
\hline 12. I can re-locate a specific web page \\
\hline
\end{tabular}

2. Evaluation of Data

\begin{tabular}{|rl|}
\hline 1. I am able to judge the degree to which information is practical or satisfies the needs of the \\
task
\end{tabular}

3. Data Management

1. When I store a file, I give it a specific name

2. I store my files in designated folders

3. I tag my information 
4.

Data processing

1. I am able to interpret information from multiple sources

2. I am able to analyse information from multiple sources

3. I am able to synthesize information from multiple sources

4. I am able to write an appropriate response to a post

5. I am able to use ICT to design or create new information from information already acquired

6. I am able to visually organize data for learning purposes

7. I can represent knowledge in a variety of ways such as PPT, website, blogs, etc.

8. I am aware of the difference in written, graphic or video representations

5. Teamwork

\begin{tabular}{|ll|}
\hline 1. & During the preparation of a joint task I know how to fit in among team members \\
\hline 2. & During the preparation of a joint task I share my thoughts and insights with my peers \\
\hline 3. & During the preparation of a joint task I know that I have an influence on the work process \\
\hline 4. & During the preparation of a joint task I know what is expected of me \\
\hline 5. & While performing a joint task I feel that my contribution to the team is meaningful \\
\hline 6. & My peers are aware of my abilities and of what I can contribute \\
\hline 7. & I have no reservation regarding joint tasks \\
\hline 8. & I like to work with my peers on a joint task \\
\hline
\end{tabular}

6.

Integrity awareness

1. I understand the ethical consequences of the use of technology

2. I understand the social consequences of the use of technology

3. I do not acquire digital information, files, programs, databases, etc., via illegal means

4. I do not use technology for purposes that are intimidating or threatening

5. I am aware of the prohibition of illegal file download

6. I am aware of copyright issues

7. I am aware of appropriate acknowledgement of sources I use

8. I am aware of the danger to my data of being online

9. I am aware of cyberbullying issues

10. I am aware of identity theft issues

11. I am aware of e-theft issues

12. I am aware of the danger of my online activities

13. I am aware of the influence my online data has

14. I am able to identify/avoid online fraud or identity theft situation

15. I am able to protect myself from online predators

7. Social Responsibility

1. I adhere to the rules of discourse and proper behaviour in social networks

2. I make sure not to reveal information about organizations without consent

3. I make sure not to hurt others - people and organizations - online

Appendix 2: Items with low compatibility that were excluded from the final questionnaire

1. I can gather information from online databases

2. I know how to identify file types by their extension

3. Usually, I do not settle for just the results I get on the first page of search results (I also look at the following pages)

4. I can retrieve an item of information that I have previously stored on each of the devices I use (computer, phone, disk-on-key, iPad, etc.)

5. I can display information in a variety of digital configurations (such as text, graphic form, video)

6. I prefer to prepare an assignment alone rather than with friends

7. I know how to set my own schedule in order to perform tasks

8. I know the principle of Creative Commons

9. I download music and / or movies illegally

10. I do not use the web for illegal purposes 